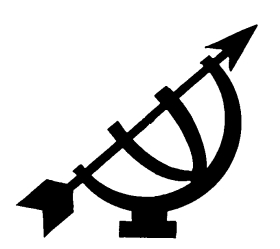

\title{
Praktykteoretiese merkers vir effektiewe en verantwoordelike integrasie van visuele elemente in die kommunikatiewe struktuur van reformatoriese prediking
}

\author{
F.W. de Wet \\ Skool vir Kerkwetenskappe \\ Potchefstroomkampus \\ Noordwes-Universiteit \\ POTCHEFSTROOM \\ E-pos: fritz.dewet@nwu.ac.za
}

\begin{abstract}
Practice theoretical markers for effective and responsible integration of visual elements in the communicative structure of reformed preaching

In this article an attempt is made to identify some essential practice theoretical markers for the introduction of visual elements in the communicative structure of reformed preaching. Introduction of visual elements is complicated in the context of the reformed tradition not only by this tradition's resistance to the use of visual elements in the liturgical environment, but also by unfamiliarity with the dynamic involved when visual elements are employed in the communicative process. In answering the first challenge posed in the foregoing article regarding the effective integration of visual elements in the communicative structure of preaching, an attempt is made to indicate a praxis in which introduction of visual elements will not disturb the essential structure of preaching (God speaking his Word) and will not curb the believer's primary instrument of perception (looking further into the spiritual dimension through faith). In answering the second challenge posed in the foregoing article regarding responsible integration of visual elements in the communicative structure of preaching, an attempt is made to indicate a praxis in which a distinction is made between visualisation that draws the listener/perceiver into earthbound thought or lack of reference to real life situations on the one hand and visualisation
\end{abstract}


that focuses the listener/perceiver in faith on God and anchors the contents of revealed truth in real life situations.

\section{Opsomming}

\section{Praktykteoretiese merkers vir effektiewe en verantwoordelike integrasie van visuele elemente in die kommunikatiewe struktuur van reformatoriese prediking}

In hierdie artikel word gepoog om enkele praktykteoretiese merkers te identifiseer vir die komplekse terrein waarop die prediker hom begewe wanneer hy visuele elemente by die kommunikatiewe struktuur van prediking wil betrek. Integrasie van visuele elemente in die kommunikatiewe struktuur van prediking word in die konteks van die reformatoriese tradisie gekompliseer deur sowel hierdie tradisie se weerstand teen die gebruik van visuele elemente in die erediens, as die onbekendheid met die dinamika wat deur die visuele in die kommunikatiewe proses ontketen word. In antwoord op die uitdaging wat in die voorafgaande artikel ten opsigte van effektiewe integrasie van visuele elemente in die kommunikatiewe struktuur van prediking gestel is, word gepoog om 'n weg aan te dui waarin integrasie van visuele elemente nie die wesenlike struktuur van prediking (wat daarin bestaan dat God aan die woord kom) versteur nie en nie die primêre waarnemingsinstrument van geloof (wat verder laat kyk tot in die geestelike dimensie) afstomp nie. In antwoord op die uitdaging wat in die voorafgaande artikel ten opsigte van verantwoordelike integrasie van visuele elemente in die kommunikatiewe struktuur van prediking gestel is, word gepoog om 'n weg aan te dui waarin onderskeid gemaak kan word tussen visualisering wat die hoorder/waarnemer enersyds in begrensdheid of ankerloosheid kan laat verval en andersyds in geloof op God rig en die werklikheid van die geloofsinhoude in die eie lewe laat sien.

\section{Inleiding en probleemstelling}

Tans is daar in reformatoriese kringe uiteenlopende standpunte oor die manier waarop visuele elemente in die erediens betrek kan word. Enersyds is daar sterk teenstand teen die gebruik van simbole en ander visuele verryking van die erediens, terwyl daar andersyds so 'n entoesiasme vir die insluiting van visuele elemente is, dat ' $n$ klakkelose oorname van enigiets "wat werk", ingevoer word (Janse Van Rensburg, 2006b:559). Janse Van Rensburg (2006a:555) meen dat die kerk nie kan bekostig om die impak van visuele tegnologie te ontken nie, maar dat daar 'n manier gevind sal moet word om daarop te reageer (vgl. Dyrness, 2001:137). In prakties-teologiese teorievorming sal indringend besin moet word oor die rol wat die 
visuele in die kommunikatiewe prosesse van die samelewing waarin die kerk ingebed is, begin speel en ook oor die implikasies daarvan vir die kommunikatiewe struktuur van prediking.

Dit kan nie ontken word dat ons in 'n tyd lewe waarin die visuele 'n toenemend groter rol in die Westerse samelewing begin speel nie. Mirzoeff (1999:6) meen dat die "wêreld-as-'n-teks" al hoe meer deur die "wêreld-as-'n-prent" in die gedagtewêreld van die Westerse kultuur vervang word. Mense begin toenemend in terme van "prentjies" dink. Die komplekse en ineengeweefde aspekte van 'n moeilike konsep, sou voorheen tipies op 'n logiese, intellektuele wyse verduidelik word. In 'n visuele kultuur is dit baie makliker om die ingewikkelde konsep deur middel van visuele voorstellings te verduidelik. Craddock (1985:201) wys op die kragtige impak wat visualisering in prediking kan maak op die vervanging van verkeerde denkbeelde in die gedagtewêreld van hoorders:

If it is the case that certain images contradict the gospel and flaw the life of the one holding them, how can preaching make a difference? Ideas and concepts are of little effect against images, and scolding does even less. Images must be replaced, and this comes only gradually, by other images.

In 'n kultuur waarin mense intuïtief al hoe meer geneig is om in prentjies te dink, sou daar besin moet word oor die wyse waarop in die kommunikatiewe struktuur van prediking gevolg gegee kan word aan hierdie tendens. Terselfdertyd moet ook daarmee rekening gehou word dat 'n kommunikatiewe proses waarin die visuele integraal betrek word, in 'n baie komplekse proses kan ontwikkel. Uit onlangse navorsing blyk dit dat die retina van die menslike oog tot 100 miljoen senuselle het wat in staat is om 10 biljoen verwerkings per sekonde te kan hanteer (Mirzoeff, 1999:5). Wanneer daar besin word oor visualisering in die homiletiese teorievorming, sal dus nie alleen aan die visuele gedink kan word in terme van die gepastheid van die prentjie wat op die dataprojektorskerm vertoon word nie, maar die fokus sal ook geplaas moet word op dit wat in die visuele verwerkingsproses in die gedagtewêreld van die hoorder/waarnemer gebeur: "Visual culture does not depend on pictures themselves but the modern tendency to picture or visualise existence." (Mirzoeff, 1999:5). Daar sal ook daarmee rekening gehou moet word dat beelde wat op die skerm vertoon word, tallose assosiasies by die waarnemer kan opwek en dat daar in sy gedagtewêreld uiteindelik 'n beeld gevorm kan word wat radikaal verskil van dit wat die prediker in gedagte gehad het met die vertoon van 'n bepaalde beeld op die skerm: 
There is a significant difference between the picture on the page and the picture in the brain: given the selective nature of our perceptual system, it is not to be expected that all optical stimuli will be treated equally. An image has been defined as the result of endowing optical sensations with meaning. (Morgan \& Welton, 1992:102.)

Wanneer visuele elemente in die kommunikatiewe struktuur van prediking betrek word, sal die prediker moet besef dat hy 'n groot verantwoordelikheid het om die visuele so in te span tydens die Woordgebeure dat daar nie 'n verkeerde beeld in die gedagtewêreld van die hoorder/kyker posvat nie. Dit sal 'n besondere uitdaging aan die prediker bied om visuele elemente op so 'n wyse te gebruik dat daar nie afbreek gedoen word aan 'n kommunikatiewe proses waarin God tydens prediking aan die Woord kom nie.

Ten einde visuele elemente op 'n effektiewe en verantwoordelike wyse in die kommunikatiewe struktuur van prediking te integreer, behoort die prediker 'n begrip te kweek vir die dinamika wat in die kommunikatiewe proses intree wanneer visuele elemente ingespan word. 'n Sleutelvraag kan wees: Wat is die verskil tussen 'n oordragproses waarin hoorders woorde ontvang en die betekenisdraagwydte van woorde moet verwerk en 'n oordragproses waarin 'n visuele voorstelling aan ' $n$ waarnemer vertoon word en die impak wat die beeld op sy gees maak, verwerk moet word? Die doel van teorievorming sal wees om 'n weg te vind waarin die beeld op 'n effektiewe wyse in die kommunikatiewe proses betrek word, sonder dat die boodskap wat in die Woordgebeure ter sprake kom, ontspoor word.

Hierdie artikel dien as die opvolg van 'n vorige artikel (De Wet, 2007) waarin, in 'n aanvanklike verkenning op basisteoretiese vlak, oor die integrasie van visuele elemente in die kommunikatiewe struktuur van prediking besin is. In die voorafgaande artikel is twee uitdagings geïdentifiseer waarvoor die reformatoriese benadering ten opsigte van die kommunikatiewe struktuur van prediking in die konteks van 'n visuele kultuur te staan kom:

- Voortvloeiend uit die eerste uitdaging sal 'n weg aangedui moet word vir effektiewe integrasie van visuele elemente in 'n tyd waarin daar 'n oorgang van 'n literêre na 'n postliterêre kultuur plaasvind. Daar sal 'n weg gevind moet word waarin die integrasie van visuele elemente nie die wesenlike struktuur van prediking (wat daarin bestaan dat God aan die woord kom) 
versteur nie en nie die primêre waarnemingsinstrument van geloof (wat verder kyk tot in die geestelike dimensie) afstomp nie.

- Voortvloeiend uit die tweede uitdaging sal 'n weg aangedui moet word vir verantwoordelikheid in die wyse waarop visuele elemente by die kommunikatiewe struktuur van prediking betrek word. Onderskeidingsvermoë sal aan die dag gelê moet word om die verskil te bepaal tussen elemente wat visualisering begrens of ankerloos maak en aan die ander kant, elemente wat visualisering in geloof op God rig en 'n mens die werklikheid van die geloofsinhoude in die eie lewe laat raaksien.

In hierdie artikel word 'n poging aangewend om op 'n meer praktykteoretiese vlak enkele treë te gee in antwoord op die twee uitdagings wat gestel is.

\section{Praktykteoretiese merkers vir effektiewe integrasie van visuele/interaktiewe elemente in die kommunikatiewe struktuur van prediking}

In 2.3 van die voorafgaande artikel (De Wet, 2007) is die uitdaging ten opsigte van effektiwiteit in die kommunikatiewe struktuur van prediking in 'n tyd waarin 'n oorgang plaasvind van 'n literêre na 'n postliterêre kultuur, soos volg geformuleer:

- Die reformatoriese tradisie (waarin prediking primêr as 'n Woordgebeure beskou word wat op 'n mondelinge wyse ingerig word) sal moet besin oor die noodsaak van en die vlak waarop die dimensie van die visuele en die interaktiewe in die eie benadering geïntegreer kan word. Dit sal 'n uitdaging wees dat hierdie elemente nie op so 'n manier geïntegreer word dat die wese van prediking (God wat aan die woord kom) in die proses in gedrang kom en vervang word deur 'n struktuur waarin die mens 'n interaktiewe verbeeldingsvlug onderneem nie.

- 'n Tweede dimensie van die uitdaging is daarin geleë dat die insluiting van visuele elemente in die kommunikatiewe struktuur van prediking, ter wille van effektiewe kommunikasie, op so 'n manier geskied dat dit nie tot afstomping en veroppervlakkiging van die primêre waarnemingsinstrument van die geloof lei nie. Visualisering waarin by die sigbare en materiële sfeer (die hier en nou) vasgesteek word, kan die geloofsoog in onaktiwiteit laat verval.

Daar word vervolgens 'n poging aangewend om hierdie twee dimensies van die uitdagings wat ten opsigte van effektiewe integrasie van 
visuele elemente in die kommunikatiewe struktuur van prediking gestel is, op praktykteoretiese vlak te konkretiseer.

\subsection{Hou rekening met die unieke kommunikatiewe struktuur van prediking}

Alhoewel daar ooreenkomste is in die basiese struktuur van kommunikatiewe sisteme in die kerklike praksis sowel as in ander samelewingsverbande, moet daarmee rekening gehou word dat elke sisteem sy eie karakter het (Pieterse, 1987:21). In die kerklike praksis kom 'n kommunikatiewe sisteem ter sprake waarin nie bloot menslike gedagtes oor God gekommunikeer word nie, maar waarin geglo word dat God aan die woord kom deur die homiletiese handelinge van ' $n$ prediker. Daar is ' $n$ verskil tussen die interaktiewe dimensie van sisteme waarin daar bloot op intermenslike vlak gekommunikeer word en 'n sisteem waarin daar in geloof verwag word dat die stem van God gehoor sal word en lewende gemeenskap met Hom bewerkstellig sal word. In simmetriese intermenslike kommunikasie vind 'n soort interaksie plaas waarin die hoorder/waarnemer self bepaal wat hy van die boodskap gaan maak. In die a-simmetriese patroon van geloofskommunikasie is daar wel interaktiwiteit in die sin dat God en mens op persoonlike vlak ontmoet en dat daar 'n hartlike en gewillige deelname van albei kante is. Immink (2005:134) stel die interaktiewe dimensie van die geloofsverhouding soos volg:

Our communion with God is personal in nature and demand a sincere assent from us; therefore, it is always a matter of Word and Spirit, of Word and faith. The faith relationship implies a personal and mutual involvement of God and humans. God speaks and we hear; God promises and we trust; we pray and call, and God hears ...

Die struktuur van geloofskommunikasie is egter a-simmetries in die sin dat die mens volledig afhanklik is van God se openbarende handeling in Christus. Die hoorder/waarnemer wil van harte niks anders hoor of sien as wat God se bedoeling met die kommunikatiewe gebeure is nie. Hy is kinderlik afhanklik van 'n openbaring waarin aspekte, wat vir hom andersins verborge sou bly, oopgemaak word. Hy weet dat die geheimenisse wat vir hom oopgemaak word andersins nooit in die hart of gedagtes van enige mens sou kon opkom nie. Hy wil alleen dit wat God aan hom bekend maak, toeëien en besef dat 'n eie verbeeldingsvlug hom net met arm, eng en eensydige perspektiewe op die omvangrykheid van God se genade sal laat. 
Wanneer hierdie unieke karakter van geloofskommunikasie in ag geneem word, is daar bepaalde implikasies vir die kriteria waarmee praktykteoretiese afleidings vir die effektiewe integrasie van visuele elemente in die kommunikatiewe struktuur van prediking gemaak word. Visuele elemente word nie in die kommunikatiewe struktuur van prediking op ' $n$ manier betrek waarin aan die hoorder/waarnemer vrye teuels gegee word om 'n verbeeldingsvlug te ondergaan en 'n denkbeeld gevorm word wat nie ooreenstem met die Woord van God nie. Janse van Rensburg (2006b:562) wys byvoorbeeld daarop hoe God in 'n kunswerk net as mooi beskryf kan word, terwyl sy heiligheid en geregtigheid nie tot sy reg kom nie. Verabsolutering van kuns (estetisisme) vind plaas wanneer die aandag van die gemeente op die skone van die kuns gevestig word in plaas daarvan dat die kuns dienstig aan die liturgiese proses word, naamlik om die aandag op God te rig. Dit gebeur wanneer die kunstenaar se mooi skildery die aandag en lof kry, in plaas daarvan dat dit die gemeente help om God te verheerlik. Die visuele kan wel veral op 'n vlak betrek word wat met konkretisering en kontekstualisering van die Woord te doen het. In 'n tyd waarin mense "in prentjies dink", sal die Woord nie abstrak in die lug kan bly hang nie. Prediking sal, kragtens die literêre styl waarin dit tradisioneel gegiet is, die waarheid wat in die Woord geopenbaar word nie alleen goed verduidelik en verklaar nie, maar ook in die postliterêre konteks van 'n visuele kultuur moet aantoon hoe hierdie geopenbaarde waarheid in die hoorder/waarnemer se wêreld deurbreek. Die hoorder/waarnemer moet in staat gestel word om die waarheid te kan visualiseer. Daar sal nie alleen aan die hoorder/waarnemer 'n abstrakte konsep van lig wat tot lewe lei, verduidelik word nie, maar hy sal moet sien hoe hierdie lewende lig die duisternis opklaar in sy konkrete lewenswêreld.

Die vraag is egter watter metodes gebruik kan word om die werklikheid van God se genade en die waarheid van die Woord in die eie lewe te visualiseer, sodat dit nie by abstrakte konsepte bly nie.

- Tradisioneel is beeldryke taal as 'n potensieel kragtige kommunikatiewe medium ingespan om die hoorder die werklike teenwoordigheid van die koninkryk van God te laat visualiseer:

Because sermons 'bring into view' unseen reality, they will of necessity, dabble in metaphor, image, illustration, and all kinds of depiction. After all, preaching is preoccupied with Christ who comes to us as story, and as a living symbol; thus, preaching is bound to tell stories and explore images. Inescapably, preaching is a work of metaphor. (Buttrick, 1987:113.) 
Deur metaforiese taal het die prediker 'n kragtige instrument om verbande tussen die sigbaar-konkrete werklikheid en 'n ander goddelike werklikheid te lê. Cilliers (2003:32) wys daarop hoe die gebruik van woordkuns in prediking die verbeelding van die hoorder kan ontsluit. Woordkuns kan mense se persepsie van die werklikheid, ook van ou, bekende dinge verander. Hierdie taal wat persepsies verander, is volgens Cilliers meer as blote diskursiewe taal. Dit is eerder presentatiewe taal waarin werklikhede nie alleen beskryf word nie, maar inderdaad gepresenteer word, verwerklik word. Dit is taal wat 'n mens uitnooi na en innooi in 'n ander wêreld, in 'n ander realiteit en daar veranderend op jou inwerk.

- Nie alleen beeldryke taal nie, maar ook die vorm waarin 'n preek gegiet word, kan aangewend word in ' $n$ poging om prediking relevant en aktueel te maak. Kirsner (2006:310) verwys byvoorbeeld na die homiletiese benadering van Martin Nicol waarin ' $n$ dramaturgiese preekvorm ontwikkel word:

Diese orientiert sich nicht mehr am Paradigma der Vorlesung, sondern an dem des Films. Nicol zeichnet den Film als eine Zeitkunst, die wesentliche Teile ihrer Inszenierungstechnik aus den Quellen der Bibel schöpft. Der performative Charakter lebendiger Kommunikation wird deutlich: Der Text der Predigt wird als Bewegung in Zeit und Raum inszeniert.

- In postliterêre konteks sal dit dalk nodig wees om een stap verder te gee in die rigting van verkonkretisering van die boodskap van die Woord deur saam met "presentatiewe" taal en narratiewe, dramaturgiese preekstyl ook 'n gepaste visuele voorstelling op 'n dataprojeksieskerm te vertoon. ' $n$ Video-insetsel uit ' $n$ onlangse nuusbulletin of 'n foto uit 'n dagblad kan heromraam word deur die helder lig van die evangelie op die ontredderdheid van daardie toneel te laat skyn. Op so 'n manier kan daar vir die hoorder duidelike verbindingslyne tussen die roeping wat in die Woord van die Here aan die Christen toevertrou word en daaglikse lewensituasies getrek word. Aan die hoorder word die geleentheid gegee om deur die oë van God na die werklikheid waarin hy leef, te kyk. Schultze (2004:72) bevestig, na aanleiding van 'n ondersoek wat hy in verskeie kerke oor die effektiewe integrasie van visuele media gedoen het, dat die gebruik van insetsels die hoorder met nuwe oë na sy leefwêreld te laat kyk: "In some churches these clips can help to furnish the con-gregants with a prophetic perspective on the world outside the sanctuary." Integrasie van visuele elemente in die kommuni-katiewe struktuur 
van 'n preek moet egter so plaasvind dat dit nie die aandag van die Woordverkondiging aftrek of bloot ter wille van versiering of effek ingesluit word nie. Die insluiting van 'n visuele element behoort organies uit die bedoeling van die teks voort te vloei en altyd die wesenlike reflekteer van die kragtige impak wat die Woord van God op hierdie sigbare wêreld maak. Gemeentelede vind dit steurend wanneer allerlei natuurtonele (hoe mooi ook al) op die skerm vertoon word wat op geen wyse met die inhoud van die liturgie verband hou nie (Janse van Rensburg, 2006b:565).

\subsection{Geloofswaarneming en geloofsgemeenskap}

Wanneer visuele elemente op 'n onnadenkende en kunsmatige manier in die kommunikatiewe proses betrek word, kan geloofswaarneming afgestomp word en die egtheid van geloofsgemeenskap met God en medegelowiges in die gedrang kom.

Flanagan (2004:7) wys daarop dat een van die belangrikste kenmerke van die hedendaagse visuele kultuur is dat die kyker sy waarneming in sy privaatwêreld maak: "The viewer has many names but all point to a property of the hidden: the lurker, the voyeur, the connoisseur who collects for privacy in looking." Die waarnemer kan in isolasie na 'n toneel kyk sonder dat hy by die situasie betrokke hoef te raak. Die nood van die mensdom soos dit by wyse van 'n insetsel op TV-nuus grafies voorgestel word, kan daar waar die kyker op sy privaatrusbank sit, op 'n veilige afstand gehou word. lemand kan die virtuele wêreld van 'n Internetgeselskamer betree en verhoudings aanknoop en moontlikhede verken wat korrespondeer met dit wat nie in die "werklike lewe" moontlik sou wees nie. Die eie liggaam word nie in die wêreld van virtuele realiteit saamgeneem nie (Meecham \& Sheldon, 2000:129). Jewell (2004: 57) beskryf die generasie wat in 'n digitale eeu moet grootword soos volg:

They are technologically savvy, and at the same time, they are emotionally vulnerable. During a time in life when they are experiencing the chaos of identity formation most forcibly and testing out who they are in the crucible of family life, they are searching for meaning and connection. One of the ways life is different in our digital world is the fact that much of this searching is accomplished in a virtual world.

In praktykteoretiese besinning sal duidelik rekening gehou moet word met die assosiasie wat die gebruik van tegnologiese media by die hoorder/waarnemer kan opwek. Tegnologie sal op so 'n manier betrek moet word dat die hoorder/waarnemer besef dat hy nie met 
beelde te doen kry wat getrivialiseer kan word nie. In die manier waarop tegnologie in die kommunikatiewe struktuur van prediking betrek word, moet dit vir die hoorder/waarnemer baie duidelik gemaak word dat die verhoudings waartoe die Woordverkondiging oproep nie in die kunsmatige betrokkenheid van 'n virtuele wêreld voltrek kan word nie.

Die volgende praktykteoretiese oorwegings kan van wesenlike belang wees vir die besinning rondom die integrasie van visuele elemente in die kommunikatiewe struktuur van prediking:

- Schultze (2004:22) maak 'n belangrike waarneming oor die manier waarop blootstelling aan 'n visuele kultuur en die ooraanbod van inligting wat daarmee gepaard gaan, die aandag van wesenlike dinge kan aftrek:

Our visually saturated culture is filled with evil as well as trivial noise that continually diverts our attention from anything important and makes it more difficult for us to focus on meaningful practices that carry eternal weight. Communication technologies can contribute to this confusion just as much as they can help us to overcome it.

Die kuns is om 'n manier te vind waarin die gebruik van kommunikatiewe tegnologie dien tot diepgang in die verstaan van die Woord, eerder as dat dit so oordonderend word dat die Woord op die agtergrond verdwyn. Oormatige gebruik van kommunikasietegnologie sou die hoorder terugneem na die rusbank in die TV-kamer en hom na die "modus van die afstandbeheerknoppie" laat oorskakel. Daar word met die afstandbeheer deur al die TV-kanale gekliek sonder dat enige van die inhoud deurdink hoef te word. Dit sou eerder sinvol wees om spaarsamig om te gaan met die insluiting van visuele elemente en om beelde net op die skerm te vertoon wanneer die inhoud wat daardeur gekommunikeer wil word in die mondelinge preek ter sprake kom. Wanneer die visuele beeld weer verdwyn en die skerm tot rus kom, gee dit geleentheid vir die waarnemingsinstrument van die geloof om dit waarvan ons net die begin gesien het, in die lig van die Woord wat gehoor word, verder te oordink en dit te kontekstualiseer in die onpeilbare wydtes van die koninkryk van God.

- Jewell (2004:113) wys op die manier waarop die ondeurdagte gebruik van teks in dataprojeksies die kommunikatiewe proses wat in prediking ter sprake kom, voorspelbaar kan maak: 
Technology functions as a more stylish way of place-marking. The worshipper can now know at all times approximately how much longer the sermon will last because they are able to follow an outline projected on the screen. Information is revealed before one's very eyes as words appear in the outline's blanks. This use of technology could cause one to conclude that the faith is not so much a mystery to be explored as it's a puzzle to be solved.

Jewell se punt is dat 'n prediker (ten spyte van die edele bedoelings om die aandag van die hoorders te trek en te behou), sonder dat hy dit besef, meer skade as goed kan doen. Dit sou vir 'n prediker nodig wees om hom eers goed te verantwoord oor die impak wat 'n bepaalde inkleding van 'n visuele element op die gees van die hoorders sal hê, voordat hy dit blindelings, omdat dit die belofte van effektiewe kommunikasie inhou, aanwend. Wanneer 'n statiese preekskets op 'n dataprojektorskerm vertoon word, kan die indruk geskep word dat die verkondigde Woord voorspelbaar en sonder deurbrekende krag is, of dat die hoorder self kan kies by watter punte hy/sy aanklank vind (vgl. Willimon, 2007:34). Geloof kan in die proses afgestomp word om op 'n eendimensionele plat vlak oor die inhoud van die Woord en die werking van die Woord te dink. Dit sou eerder oorweeg kon word om 'n preekskets op 'n ontvouende wyse te hanteer en die lewende krag wat in sleutelwoorde of gedagte-ontwikkelings in die teks geleë is, te beklemtoon, deur byvoorbeeld van geanimeerdheid in teksuitleg gebruik te maak. Wanneer die ligduisternismetafoor byvoorbeeld in 'n teks ter sprake kom, kan die woord "duisternis" op die skerm wegsmelt, wanneer die woord "lig" daarop ontvou.

- Die prediker behoort ook 'n begrip en fyn aanvoeling te kweek vir die assosiasie(s) wat sy gebruik van visuele elemente kan opwek by hoorders wat hulle daagliks in die atmosfeer van die tegnologiese eeu bevind. Jewell (2004:23) onderskei tussen tegnologiese konneksie (connectivity) en persoonlike konneksie (connection). Deur middel van TV-uitsendings, Internet, geselskamers of selfoonboodskappe word connectivity bewerkstellig. Hierdie instrumente hou die belofte in om die gebruiker in kontak met sy wêreld te bring, maar dit kan die kommunikasie tussen mense, sonder die werklike connection van 'n van-aangesig-totaangesigontmoeting, tot virtuele kontak in die kuberruimte laat vervlak. Visuele elemente behoort op so 'n manier betrek te word dat dit nie die assosiasie van connectivity opwek nie, maar daartoe lei dat werklike verbintenis gemaak word met God, mede- 
gelowiges en mense in die wêreld. In die wyse waarop tegnologie in die kommunikatiewe struktuur van prediking betrek word, moet dit vir die hoorder baie duidelik gemaak word dat die verhoudings waartoe die Woordverkondiging oproep nie in die kunsmatige betrokkenheid van 'n virtuele wêreld voltrek kan word nie. Die prediker sal dit egter altyd duidelik moet maak dat die atmosfeer in die erediens in die egtheid van ware geloofsgemeenskap met God en die medegelowiges staan. Waar die lewende God in sy brandende liefde vir die gelowiges en vir hierdie wêreld teenwoordig is, kan daar nie in passiwiteit verval word nie. Dit sou oorweeg kon word om beelde uit die plaaslike koerant of foto's van bekende situasies in die leefwêreld van die hoorders in die kommunikatiewe proses te integreer, sodat die assosiasie van kunsmatigheid en afstandelikheid daardeur verbreek kan word. Sulke visuele beelde - geïntegreer met en heromraam deur die verkondiging van die Woord - kan 'n kragtige kommunikatiewe medium wees om hoorders se oë oop te maak vir aspekte in hulle leefomgewing waarvoor hulle afgestomp geraak het.

Tydens hierdie eerste rondte van praktykteoretiese besinning, het dit duidelik geword dat kommunikatiewe tegnologie nie kritiekloos uit die kommunikatiewe strukture van die wêreld in die ruimte van die erediens ingetrek kan word nie. Met die waarnemingsinstrument van die geloof is visualisering nie beperk tot die sigbaar-konkrete dimensie van die werklikheid en die private, virtuele en triviale invalshoek waarmee dit dikwels waargeneem word nie. Met die oë van die geloof word die sigbaar-konkrete op 'n verruimde manier in die verbintenis daarvan aan God beskou. Met die oë van die geloof word ook met 'n verskerpte blik na die nood in die sigbaar-konkrete gekyk; 'n verskerpte blik op nood wat ten diepste roep om versoening met God. Die unieke kommunikatiewe struktuur wat in Woordverkondiging ter sprake kom asook die kardinale plek van die waarnemingsinstrument van die geloof, stel hoë vereistes aan die manier waarop visuele elemente by die kommunikatiewe struktuur van prediking betrek word. Daarom is dit nodig om ook op praktykteoretiese vlak 'n tweede rondte van besinning te onderneem, waarin die uitkristallisering van visuele elemente in die kommunikatiewe struktuur van prediking met verantwoordelikheid deur 'n nog fyner sif gestuur word. 


\section{Praktykteoretiese merkers vir die verantwoordelike integrasie van visuele/interaktiewe elemente in die kommunikatiewe struktuur van prediking}

In afdeling 3.3 van die voorafgaande artikel (De Wet, 2007) is die uitdaging wat aan die reformatoriese benadering ten opsigte van verantwoordelike integrasie van visuele/interaktiewe elemente in die kommunikatiewe struktuur van prediking gestel is, onder die noemer van onderskeidingsvermoë gebring.

Die uitdaging vir die reformatoriese benadering is omlyn as ' $n$ verantwoordelikheid om toe te sien dat al die faktore wat by die homiletiese proses betrokke is met onderskeidingsvermoë nagegaan word, om sodoende die juiste plek van visuele elemente in die kommunikatiewe struktuur van prediking aan te dui.

Daar is aangedui dat daar in die integrasie van visuele elemente in die homiletiese proses met die volgende faktore rekening gehou behoort te word:

- In prediking word 'n Woord verkondig waarin daar sprake van Godsopenbaring is. Onderskeid behoort getref te word tussen transendente en immanente aspekte in die Godsopenbaring. Onderskeidingsvermoë (in die Pneumatologiese konteks waarin die prediker hom onder leiding van die Gees van Christus stel) bewaar die prediker daarvan om onvoorstelbare elemente in Godsopenbaring tot die vlak van voorstelbaarheid, uitbeeldbaarheid en manipuleerbaarheid te verlaag. Maar onderskeidingsvermoë stel die prediker wel in staat om visuele elemente op so 'n manier in die homiletiese proses te integreer, dat bewyse van God se genade in ons sigbaar-konkrete bestaan nie teoreties en abstrak in die lug bly hang nie.

- In prediking bly die Woord van God, soos dit in die Bybelse teks op skrif gestel is, die enigste vertrekpunt vir die vasstelling van die inhoud en boodskap van 'n preek. Onderskeid behoort getref te word tussen elemente wat getrou bly aan die inhoud en bedoeling van die Bybelse teks en elemente waarin daar iets by die Woord bygevoeg word, of iets daarvan weggeneem word.

- Ook ten opsigte van die ontvanger (hoorder) van die boodskap van 'n preek behoort onderskeid getref te word tussen visuele elemente waarin die betrokkenheid van die Woord van die lewe van die hoorder geïsoleer word en visuele elemente waarin die 
hoorder se bestaan gekontekstualiseer word in die onpeilbare dimensies van die koninkryk van God.

\subsection{Transendente en immanente aspekte in Godsopenbaring}

Onderskeidingsvermoë is nodig in die manier waarop transendente en immanente aspekte in Godsopenbaring visueel uitgebeeld kan word. Wanneer besin word oor die verhouding tussen Godsopenbaring en visuele voorstellings in die kommunikatiewe struktuur van prediking, sal onderskeid getref moet word tussen transendente en immanente aspekte van geloofsvisualisering. Dit wat onvoorstelbaar is, kan nie in die sigbare werklikheid gelokaliseer en gemanipuleer word nie. Dit wat lewensveranderend in die konkrete bestaan van die gelowige deurbreek, kan egter nie abstrak in die lug bly hang nie. Die enigste maatstaf vir 'n lewensgetroue visualisering van die manier waarop God Hom aan ons openbaar, is die manier waarop ons in Christus sien hoe God tot ons kom, en ons in ons lewe sien hoe ons in Christus tot die beeld van God vernuwe word:

- In Christus het die Woord vlees geword en onder ons kom woon. Deur die Seun alleen kan die Vader, wat nog nooit deur iemand gesien is nie, bekend gemaak word (Joh. 1:18). Deur die optrede van die Seun word die volle spektrum van die krag en wysheid van God sigbaar. Buttrick (1987:121) stel die sentrale plek van Jesus Christus, as God-met-ons, as die kriteria waarvolgens visualisering in prediking ingerig moet word, soos volg:

In managing language of analogy we will allow our words to be ruled by the 'Word become flesh', Jesus Christ. Christ is the living Metaphor of God-with-us. The nailed-down, suffering love of Christ crucified counters our tendency to blow the attributes of God into idolatry by our own tenacious will-to-be-God. At the same time, Christ's presence as a living symbol prevents us from absorbing God's nature into images of our human nature; Christ is different. Thus, we need not fear the language of analogy. Christ as 'Word become flesh' blesses a language of analogy. Yet, the nature of Jesus Christ protects every analogy: his radical humanity counters idolatry, and his mysterious divinity prevents trivial analogy. Jesus Christ, the Living Metaphor of God-with-us, watches over the language of preaching.

Alhoewel Buttrick hier primêr verwys na analogie soos dit in taalgebruik ter sprake kom, sou dieselfde beginsel op visuele dataprojektorbeelde toegepas kon word. Die aard van die lig wat met die koms van Jesus Christus in die wêreld deurbreek, sou 
byvoorbeeld nie met die analogie van 'n triviale, romantiese foto waarin 'n sagte sonsopkoms die grys lig verkleur, voorgestel kan word nie. So 'n beeld sou afbreuk doen aan die glansrykheid van hemelse genade wat in Christus, die Seun van God, die houvas van 'n swart nag verbreek. Ook sou dit onvanpas wees om kunstenaarsvoorstellings van Jesus se liggaamlike bestaan in visualisering te gebruik. Geen kunstenaar kan die volle rykdom van God se wysheid en krag, soos dit in Jesus Christus geopenbaar word, ooit in een beeld vasvang nie. Geen mens is in staat om sy Godheid uit te beeld nie. Gevolglik sou die kunstenaar moes volstaan met ' $n$ uitbeelding van sy mensheid. Dit beteken dat Christus uiters eensydig uitgebeeld sou word (De Bruyn, 1993:74; vgl. Van der Merwe, 1968:16).

- Deur Immanuel (God-met-ons) word ons konkrete menswees vrygemaak om op God gerig te wees. Deur lyding heen word ons na die beeld van Christus vernuwe om ons lewensvoleindiging in die heerlikheid van Godgerigtheid te vind (Rom. 8:17). In ons konkrete bestaan kan die bewyse van God se genade gesien word. Beelde uit die daaglikse lewe van gelowiges kan met vrug vir visualisering in die kommunikatiewe struktuur van prediking gebruik word; beelde van mense wat ondanks aardse lyding, kragtens die vernuwende werk van die Gees van Christus, 'n blymoedigheid en lewende hoop uitstraal; beelde waarin die manier waarop mense hulle lig laat skyn, uitloop daarop dat hulle Vader wat in die hemel is, verheerlik word.

- Wanneer van metafore of simbole gebruik gemaak wil word ten einde die gelowige hoorder/waarnemer in Christus op God te rig, behoort onderskeid getref te word tussen visualisering waarin die hemelse majesteit van God en sy hemelse seëninge afgetrek word in die beperkende ruimte van die sigbare, aardse werklikheid en visualisering wat as lanseerplatform dien vir die hart en die gedagtes om omhoog te gaan en op die dinge daarbo te fokus waar Christus aan die regterhand van God is. Die doel van die prediker met die vertoon van 'n visuele beeld op 'n dataprojektorskerm sal wees om die hoorder/waarnemer van 'n kyk met fisiese oë te begelei na die eintlike waarneming deur die oë van die geloof.

In die bepaling van die manier waarop visualisering instrumenteel kan wees om die menslike gees voor die werklikheid van die onsigbare en geestelike elemente van sy geloof te stel, kan na die gedagtes van Calvyn rondom die funksie van die sakramente verwys word. Dyrness (2004:70) wys daarop hoe die sigbare tekens 
in die sakramentsbeskouing van Calvyn as instrumente dien om die gelowige tot 'n ware geloofsontmoeting met Christus te lei:

Calvin uses the language of touch and sight frequently with respect to the sacraments. The purpose of the signs is 'to direct and almost lead men by hand to Christ, or rather as images, represent him and show him forth to be known' (Inst. IV. XIV. 20). But here again these senses become metaphors for the inward appropriation of Christ by faith.

Die feit dat die mens aardsgebonde in sy denke is en van nature nie daartoe in staat is om geestelike dinge te bedink nie, verhinder, volgens Calvyn, nie God om in sy onmeetlike goedertierenheid by ons beperkte begripsvermoë aan te pas nie. In sy goedheid gebruik God aardse elemente om ons tot Hom te lei en gebruik Hy die sigbare werklikheid soos 'n spieël waarin geestelike seëninge weerspieël word (Calvyn, 1992 [1559] Inst. IV. XIV. 3).

Alhoewel die visuele elemente wat in die sakramente ter sprake kom (water, brood en wyn) 'n unieke geloofsversterkende krag en waarde het, verhinder dit nie die prediker om visuele beelde (soos 'n rots as metafoor vir die onveranderlike trou van God of 'n wynstok en lote as metafoor vir die lewensverkwikkende gemeenskap met Christus) te gebruik om die geloof op die werklikheid van God se teenwoordigheid in ons lewens te rig nie. De Bruyn (1993:76) wys daarop dat God so onuitspreeklik groot is dat daar nie anders as met simbole en vergelykings oor Hom gepraat kan word nie. Daar moet egter altyd onthou word dat God nie identies met die simboolanalogie is nie en dat sy wese so uniek is dat dit uitstyg bo alle metafore.

Buttrick (1987:119) wys op die gebrekkigheid van analogie en die versigtigheid waarmee dit gebruik moet word:

Analogy is the language of faith. Yet analogy in and on itself is insufficient. Analogy draws the mystery of God into the human world, but in so doing it can easily domesticate God and make the gospel trivial. Because analogy is a language of 'like', it can make God like us; God's love like our loves; God's sovereignty like authority in our political systems; God's kingdom like our moral spheres. The obvious danger in analogy is that it can paint our image on the face of God and scale down God's revelation to our conventional wisdoms ... (vgl. Immink, 2005:226). 
Buttrick (1987:119 e.v.) wys hoe die taal van versterking (amplification) en dialektiese taal van ontkenning (denial) behoort gebruik te word ten einde analogie in perspektief te bring. Wanneer die analogie van die liefde van 'n aardse ouer vir sy kind gebruik word, behoort ' $n$ element van versterking altyd ingebou te word ten einde die onvergelykbaarheid van God se liefde tuis te bring. 'n Versterkende stelling kan soos volg lui: "Hoeveel te meer het God ons lief." Ook die taal van ontkenning kan gebruik word om die analogie te kwalifiseer, of dit deur paradoks te omraam. Die analogie van die liefde van 'n aardse ouer vir sy kind sal dadelik gekwalifiseer word met 'n stelling soos: "Selfs ons beste liefde kan nie 'n druppel wees in die fontein van oorvloedige liefde wat uit ons hemelse Vader voortvloei nie." Analogie kan ook paradoksaal omraam word met 'n stelling soos: "God se liefde is nie soos ons liefde nie."

Wanneer ' $n$ visuele voorstelling van 'n metafoor op 'n dataprojeksieskerm vertoon word (bv. 'n beeld van 'n ouer wat 'n kind in albei arms omvou), moet gepoog word om die uitbeelding so eenvoudig en natuurlik as moontlik te hou en behoort die prent net vertoon te word vir so lank as wat die metafoor in die mondelinge preek ter sprake kom. 'n Eenvoudige, dog aangrypende visuele voorstelling soos Rembrandt se ets van die gelykenis van die verlore seun (1636) kan hier met vrug gebruik word. In hierdie voorstelling slaag Rembrandt daarin om uitdrukking te gee aan die één gedagte wat deur Christus in hierdie gelykenis gelê is, naamlik volkome vergewing teenoor volkome verlorenheid. Veral die manier waarop die verlore seun in Rembrandt se uitbeelding omvou word deur die twee hande van die vader - die een hand in 'n vertroostende posisie en die ander in 'n ondersteunende posisie - kan op 'n besondere wyse in diens van die boodskap van die Skrifgedeelte staan (Van Gelder, 1948:44; vgl. Luk.15:11-32).

Daar moet ook rekening gehou word met die kragtige impak wat visuele voorstellings (wat bedoel is om as metafore te dien) op die menslike gees kan hê. Sonder dat die kommunikeerder dit bedoel, kan 'n gedagteketting aan die gang gesit word of 'n assosiasie opwek word wat die aandag van sy bedoeling aftrek of 'n verkeerde denkbeeld laat posvat. Morgan en Welton (1992:104 e.v.) wys op die verskillende vlakke waarop visuele voorstellings wat met 'n onsigbare saak geassosieer word, 'n impak op die waarnemer kan maak. Wanneer die beeld as 'n metafoor waargeneem word, maak die waarnemer 'n assosiasie tussen die beeld en 'n aspek van die idee/onsigbare saak in so 'n mate dat die persepsie opgewek word dat dit wat gesien word inherent dieselfde is as die aspek van die 
idee/onsigbare saak waarna verwys word. 'n Visuele voorstelling, kan die status van 'n ikoon in die gees van die waarnemer verkry, wanneer daardie voorstelling stelselmatig 'n geykte en kragtige plek in die kommunikatiewe sisteme van die kultuur waarin die waarnemer ingebed is, verkry het. Wanneer ' $\mathrm{n}$ visuele voorstelling simboliese waarde vir die waarnemer verkry, word die voor die hand liggende betekenisdraagwydte van die beeld oorspan. Vanuit die onderbewussyn van die waarnemer word 'n waarde aan die beeld toegeken en 'n assosiasie opgewek wat buite die verwagte betekenisdraagwydte val. Dieselfde visuele voorstelling ('n volwassene met albei arms om 'n kinderfiguur) kan 'n hele reeks assosiasies by verskillende mense opwek: Dit kan as metafoor die waarnemer vrymaak om die omvattende, werklike teenwoordigheid van God in sy liefde te omhels. Dit kan as ikoon ook so ver gaan om die seënende krag van God af te trek en in 'n kulturele ideologie te lokaliseer waarin die voortbestaan van 'n volk in sy toewyding en koestering van eie belange gewaarborg word. Dit kan vir iemand wat tydens sy kinderjare ouerverwerping beleef het, egter 'n leë, onrealiseerbare droom simboliseer.

\subsection{Die verhouding tussen Woord en visuele voorstelling}

Onderskeidingsvermoë is nodig in die bepaling van die juiste verhouding tussen die Woord en die visuele voorstelling wat in diens daarvan gebruik word. In die reformatoriese tradisie word prediking as Woordgebeure gesien. Die gebruik van beelde in die taalgebruik word in hierdie tradisie konsekwent in diens van die Woord geplaas. Beeldryke taal funksioneer as verheldering of illustrasie van die boodskap van die Woord. Craddock (1985:204 e.v.) skets byvoorbeeld riglyne vir die gebruik van illustrasies waarin die prediker gemaan word om beelde so eenvoudig as moontlik te hou en daarvan af te stap sodra dit sy illustratiewe funksie vervul het. Die analogie tussen die beeld en die saak waarna dit verwys, behoort so duidelik te wees dat geen verdere verduideliking van die kompleksiteite nodig sou wees nie. Mitchell (1999:36) wys daarop dat die kragtige impak van 'n beeld nie onderskat moet word nie en dat dit met versigtigheid in diens van die Woord aangewend moet word:

While a picture adds depth and colour, it can so provoke or evoke listeners' imaginations that the preacher loses their attention, or the image is remembered and the message forgotten. The unforgettable verbal image has the potential to undermine the structural integrity or plot of a sermon as it may be so powerful that it interrupts the flow of the discourse. 
In die postliterêre benadering van die visuele kultuur is daar ten opsigte van die verhouding tussen teks en beeld 'n radikale koersaanpassing gemaak:

Formerly, the image illustrated the text (made it clearer); today, the text loads the image, burdening it with culture, a moral, an imagination. Formerly, there was reduction from text to image; today, there is amplification from the one to the other. (Barthes, 1996:142.)

Kress en Van der Leeuwen (1996:179) wys ook daarop hoe die teks in ' $n$ visuele kultuur in ' $n$ mindere mate daartoe in staat is om 'n voorskriftelike rol te speel in die manier waarop betekenis toegeëien word:

Compare, for example, the classic documentary film, in which an authoritative 'voice of God' narrator explains and interprets images of recorded reality, to the more modern 'direct cinema' documentary in which control over meaning lies in the selection of images and in the sometimes hardly noticeable way in which these images are edited together.

Indien die kommunikatiewe struktuur van prediking by hierdie aspek van visuele kultuur moes aanpas, sou woord en beeld ten minste op gelyke vlak geplaas moes word en sou die woord selfs in diens van die beeld geplaas kon word. Die Woord sou dan funksioneer as 'n vonk wat die verbeelding van die waarnemer aan die gang sit en nuwe interpretasiemoontlikhede oopmaak vir die waarnemer se visie op dit wat hy sien. Die Woord sou dan nie die eerste en die laaste sê hê oor die denkbeelde wat in die gedagtewêreld van die hoorder behoort te leef nie, maar sou alleen moontlikhede oopmaak wat deur die verbeeldingskrag van die waarnemer verder gevoer kan word. Die implikasie van so 'n benadering tot die teks van die Woord blyk duidelik uit die beskouing van Kirsner (2006:310): "Biblische Bezüge sind nicht mehr selbstverständliches Fundament, sondern sie werden zum Ferment der Interpretation. Ihre Tragfähigkeit für Heute, die eben kein gesellschaftlicher Konsens mehr ist, erweist sich in der Erschliessungskraft ihrer Deutungsperspektiven."

Die reformatoriese benadering met sy kenmerkende en ononderhandelbare Solo Verbo-karakter staan kennelik teenoor die benadering waarin kommunikatiewe struktuur so ingerig word dat die Bybelse teks relatiewe waarde kry en slegs funksioneer as ' $n$ invalshoek op die betekenis waarna die hoorder op soek is vir sy lewe. In die reformatoriese benadering sal die manier waarop 'n beeld/visuele voorstelling die kommunikatiewe struktuur van predi- 
king ter sprake bring nooit aan vryheid van interpretasie oorgelaat word nie. Die funksie van die beeld/visuele voorstelling sal altyd in diens van die boodskap van die Woord staan en deur die Woord in ' $n$ bepaalde betekenisdraagwydte gekanaliseer word (vgl. Dyrness, 2001:146). Jensen (2004:302) beklemtoon die belang van komplementariteit in die verhouding tussen woorde en beelde in die prediking: "Words needs images to give them breathing room and to spark the imagination. Images need words to give them definition and meaning." Jewell (2004:118) beklemtoon ook die komplementariteit tussen teks en woord:

The imagination needs reasonable instruction even as reasonable instruction needs the imagination. Images continue to need explanations as much as explanations continue to need images. Therefore it must never be forgotten that images can illustrate beautifully, but they can also confuse. They can both strengthen and undermine the preacher's words.

In dieselfde asem kan egter gesê word dat die dienskneggestalte waarin visuele beelde geklee word, nie die waarde daarvan onnodig hoef in te perk nie. Alhoewel 'n beeld so gebruik sal word dat daar niks by die boodskap van die Woord bygevoeg, of niks daarvan weggeneem word nie, hoef die funksie daarvan nie bloot tot illustratiewe waarde beperk te word nie. Dit kan ten volle ontplooi word om die hoorder/waarnemer die volle betekenis van die Woord in sy leefwêreld te laat visualiseer ('n kontekstualiserende funksie) en om die hoorder/waarnemer voor die werklikheid van geestelike aspekte van sy geloof te stel ('n analogiserende funksie).

\subsection{Die werklikheid van die hoorder/waarnemer}

Daar moet onderskeidingsvermoë wees in die kontekstualisering van visuele elemente met betrekking tot die werklikheid waarin die hoorder/waarnemer leef. In die insluiting van visuele elemente in die kommunikatiewe struktuur van 'n preek behoort onderskeid getref te word tussen kunsmatige en verengende visuele elemente waarin die hoorder/waarnemer se visie op die betrokkenheid van die Woord by sy lewe afgestomp word, en visuele elemente waarin die hoorder/ waarnemer se bestaan gekontekstualiseer word in die omvangryke en voleindigende dimensies van die koninkryk van God.

Flanagan (2004:74) maak 'n belangrike opmerking oor hoe manipulasie van beelde deur middel van tegnologie tot dekontekstualisering en kunsmatigheid kan lei: 
Technology not only facilitates the endless de-contextualisation of images; it also makes possible forms that need no original, the visual basis being located in the digital and in cyberspace. ... In the making of images the viewer sees with no inhibition, no morality and no presumption.

Wanneer 'n digitaal gemanipuleerde beeld van 'n natuurtoneel, strokiesprentagtige karakters en lewelose en eendimensionele rekenaargrafika vertoon word, kan 'n assosiasie van kunsmatigheid opgewek word en kan die waarnemer vervreem word ten opsigte van die betrokkenheid van dit wat hy waarneem op die realiteit waarin hy lewe.

Wanneer visuele voorstellings in die prediking betrek word, behoort 'n fyn aanvoeling gekweek te word vir 'n wyse van aanbieding waarin kontekstualisering nie in die proses verlore gaan nie. Kontekstualisering het nie slegs te doen met die plasing van 'n visuele element in die konteks van sigbaarkonkrete lewensituasies in die leefwêreld van die hoorder/waarnemer nie. In hierdie opsig maak Dyrness (2001:145) die volgende opmerking:

Culture and education have taught us to see the world on its own terms - that is, without reference to God or the supernatural. Even Christians frequently forget how to connect the depths of their experience with God. They are often afflicted with the Gnostic temptation to split off God and his purposes from their everyday world.

In die Christelike geloof word nie slegs die hier en nou gevisualiseer asof dit 'n volle beeld sou kon gee van die konteks waarin die gelowige se lewe staan nie.

Kontekstualisering het ook te doen met die ankering in en oriëntering ten opsigte van die trinitariese struktuur (God die Vader en ons skepping, God die Seun en ons verlossing, God die Heilige Gees en ons voleindiging) wat bepalend is vir die manier waarop die Christelike lewe ontplooi (vgl. Dyrness, 2001:94). Cilliers (2003:19) beskou aanbidding as 'n vorm van kuns wat ons bewondering vir die Skepper, ons behoefte aan verlossing uit die gebrokenheid van ons sonde en ons lewende hoop met betrekking tot die vervulling van God se beloftes verbaliseer en visualiseer. Beelde behoort in die kommunikatiewe struktuur van die erediens op so 'n manier betrek te word dat hulle nie alleen 'n deskriptiewe funksie vervul nie, maar ook 'n kritiese en konstruktiewe funksie. In visuele voorstellings/ skyfiereekse waarin byvoorbeeld aspekte van sosiale verval, menslike ellende en maatskaplike uitbuiting uitgebeeld word, behoort die 
oë ook oopgemaak te word vir die oorspronklike bedoeling van God vir sy skepping en die lewende hoop op vernuwing waarin die Christelike geloof sy voleindigingspunt vind (vgl. Louw, 1995:10). Buttrick (1987:157) werk met die konsep van bewegings (moves) in die struktuur van 'n preek waarin 'n geïntegreerde reeks beelde ingebou kan word: "We are not merely trying to gather a bunch of 'impact' illustrations, we are designing a grid of interrelating images to serve a particular structure of thought." In die konteks van integrasie van visuele elemente in die kommunikatiewe struktuur van 'n preek, kan van 'n skyfiereeks gebruik gemaak word, waarin die "hier en nou"-situasie van 'n gebroke wêreld en die noodsaak aan verlossing wat daarin geleë is, gekontekstualiseer kan word deur beelde waarin die oorspronklike skeppingsdoel en versugting na voleindiging verreken word (vgl. Rom. 8:18-30). Die beeld van 'n verwronge hand wat in 'n vuis ineengeklem is, kan byvoorbeeld op 'n lewensgetroue, kunssinnige wyse (nie kunsmatige wyse nie) oopgebuig word in 'n hand wat seënend en beskermend uitgestrek word.

\section{Slot}

In hierdie artikel is gepoog om enkele praktykteoretiese merkers te identifiseer vir die komplekse terrein waarop die prediker hom begewe wanneer hy visuele elemente by die kommunikatiewe struktuur van prediking wil betrek. 'n Prediker wat uit die reformatoriese tradisie kom, sal goed bekend wees met die kenmerke van 'n kommunikatiewe proses wat uitsluitlik in mondelinge oordrag van die boodskap uit 'n geskrewe Bybelse teks opgaan. Wanneer die moontlikheid oorweeg word om visuele elemente (soos byvoorbeeld by wyse van 'n dataprojeksie) by die kommunikatiewe proses te betrek, sal 'n prediker uit die bogenoemde tradisie hom egter op onbekende terrein bevind. Hy sal waarskynlik nie alleen voor die struikelblok van onvaardig in die hantering van visuele elemente te staan kom nie, maar ook te doen kry met die weerstand van 'n tradisie waarin ' $n$ diepliggende twyfel ten opsigte van die kommunikatiewe waarde van die visuele ingebed is.

In antwoord op die uitdaging wat ten opsigte van effektiewe integrasie van visuele elemente in die kommunikatiewe struktuur van prediking gestel is, is gepoog om 'n weg aan te dui waarin die integrasie van visuele elemente nie die wesenlike struktuur van prediking (wat daarin bestaan dat God aan die woord kom) versteur nie en nie die primêre waarnemingsinstrument van geloof (wat verder laat kyk tot in die geestelike dimensie) afstomp nie. Die kuns 
van effektiewe integrasie sou daarin bestaan dat visuele elemente in 'n dienskneggestalte geklee word waarin die werklikheidsvernuwende aard van die Woord van God in die geloofsgemeenskap en leefwêreld van die hoorder onbevange gevisualiseer kan word.

In antwoord op die uitdaging wat ten opsigte van die verantwoordelike integrasie van visuele elemente in die kommunikatiewe struktuur van prediking gestel is, is gepoog om 'n weg aan te dui waarin onderskeid gemaak kan word tussen visualisering wat die hoorder/waarnemer enersyds in begrensdheid of ankerloosheid kan laat verval, en andersyds in geloof wat op God rig en die werklikheid van die geloofsinhoude in die eie lewe laat sien. Met behulp van onderskeidingsvermoë sou 'n fyn aanvoeling gekweek moet word vir analogiserende visuele elemente. Die analogiserende visuele elemente moet daartoe dien dat die hart vrygemaak word van aardsgebonde denke. In die kontekstualiserende visuele elemente moet die betrokkenheid van die Woord by die daaglikse lewe van die gelowige en die lewensvoleindigende aard van die koninkryksbepaaldheid van die lewe van die gelowige die doel wees.

\section{Geraadpleegde bronne}

BARTHES, R. 1996. The photographic message. (In Cobley, P., ed. The communication theory reader. London: Routledge. p. 134-147.)

BUTTRICK, D. 1987. Homiletic moves and structures. London: SCM.

CALVYN, J. 1992 [1559]. Institusie van die Christelike godsdiens. Vertaal deur H.W. Simpson. Potchefstroom: Calvyn Jubileumboekefonds.

CILLIERS, J.H. 2003. “... Meer as wat die oog kan sien ..." Kantaantekening oor die interseksie van kuns, liturgie en prediking. Praktiese teologie in Suid-Afrika, 18(1):8-42.

CRADDOCK, F.B. 1985. Preaching. Nashville: Abingdon.

DE BRUYN, P.J. 1993. Die tien gebooie. Midrand: Varia.

DE WET, F.W. 2007. Uitdagings vir 'n reformatoriese benadering tot prediking in 'n postliterêre kommunikatiewe konteks. Koers, 72(3):445-465.

DYRNESS, W.A. 2001. Visual faith: art, theology and worship in dialogue. Grand Rapids: Baker.

DYRNESS, W.A. 2004. Reformed theology and visual culture: the protestant imagination from Calvin to Edwards. Cambridge: Cambridge University Press.

FLANAGAN, K. 2004. Seen and unseen: visual culture, sociology and theology. Basingstoke: Macmillan.

IMMINK. F.G. 2005. Faith: a practical theological reconstruction. Grand Rapids: Eerdmans.

JANSE VAN RENSBURG, J. 2006a. Estetika in liturgiese konteks: 'n basisteoretiese diskoers. Nederduitse Gereformeerde teologiese tydskrif, 47(3 \& 4):547-557. 
JANSE VAN RENSBURG, J. 2006b. Kuns en liturgie: 'n praktykteoretiese refleksie op die estetika-diskoers. Nederduitse Gereformeerde teologiese tydskrif, 47(3 \& 4):558-569.

JENSEN, R.A. 2004. Thinking in pictures. Dialogue: a journal of theology, 43(4):297-303.

JEWELL, J.P. 2004. Wired for ministry: how the internet, visual media, and other new technologies can serve your church. Grand Rapids: Brazos.

KIRSNER, I. 2006. Komm und sieh! (Joh 1, 46) - Filmgottesdienst als kybernetisches Modell. Praktische Theologie (Gutersloh), 41(4):305-313.

KRESS, G. \& VAN DER LEEUWEN, T. 1996. Reading images. (In Cobley, P., ed. The communication theory reader. London: Routledge. p. 172-180.)

LOUW, D.J. 1995. Hermeneut tussen katedraal en markplein. Nederduitse Gereformeerde teologiese tydskrif, 36(1):9-13.

MEECHAM, P. \& SHELDON, J. 2000. Modern art: a critical introduction. London: Routledge.

MIRZOEFF, N. 1999. An introduction to visual culture. London: Routledge.

MITCHELL, J.P. 1999. Visually speaking: radio and the renaissance of preaching. Edinburgh: Clark.

MORGAN, J. \& WELTON, P. 1992. See what I mean? An introduction to visual communication. London: Arnold.

PIETERSE, H.J.C. 1987. Communicative preaching. Pretoria: UNISA.

SCHULTZE, Q.J. 2004. High tech worship? Using presentational technologies wisely. Grand Rapids: Baker.

VAN DER MERWE, N.T. 1968. Aspekte van 'n funksionele beskouing van verbeelding en van 'n tipologie van teorieë oor die verbeelding. Potchefstroom: $\mathrm{PU}$ vir $\mathrm{CHO}$.

VAN GELDER, H.E. 1948. Rembrandt, de etser. Amsterdam: Becht.

WILLIMON, W.H. 2007. Power pointless: the way we distill the gospel for presentation can take the life out of it. Leadership: practical journal for church leaders, 28(3):33-35.

\section{Kernbegrippe:}

effektiwiteit

kommunikatiewe struktuur

reformatoriese prediking

verantwoordelikheid

visuele elemente

\section{Key concepts:}

communicative structure

effectiveness

reformed preaching

responsibility

visual elements 